\title{
Institutional and political development of the Russian state in the context of the theory of A. Greif
}

\author{
D. N. Ermakov¹, G. G. Popov², G. N. Kaninskaya1 ${ }^{1}$, V. M. Marasanova ${ }^{1}$
}

1P. G. Demidov Yaroslavl State University, 14 Sovetskaya str., Yaroslavl 150003, Russian Federation 2RANEPA, 82 Vernadsky Ave., Moscow 119571, Russian Federation

DOI: $10.18255 / 2412-6519-2020-4-324-333$

Research Article

Full text in Russian

The purpose of this article is to test the concept of A. Greif for the operation of the principle of establishing a balance of interests in Russian society in the face of increasing external threats. The article reveals the significance of the Veche as an institution that reflected the desire to establish a balance of interests of elites in Russian society. The author traces changes in the significance of the traditions of self-government in Russian lands with the increase of military threats. The content of the balance of interests in medieval Russian society is determined. The problematic method of historical analysis is applied to the study of the political processes of medieval Russia, and the problem of narodopravstvo is brought to the fore. The conceptual idea of A. Greif is confirmed in Russian medieval history. Deviations from the rule deduced by A. Greif under certain external conditions lead society to crises. The authors point out that the easing of military pressure from the nomads on North-Eastern Russia (1408) allowed the Moscow princes to concentrate their efforts on fighting potential internal opposition and other branches of the Rurik dynasty that occupied the great tables, as well as against the Novgorod Republic, which embodied the ancient Slavic state order. In the course of this struggle, the balance of interests between strata of Russian society was disrupted, which eventually resulted in the establishment of a brutal serfdom and a reactionary form of centralized government - autocracy. In South-Western and North-Western Russia, such conditions did not develop, so the old Slavic order was preserved there for a long time, but, due to military and political reasons, the States in these regions did not manage to maintain independence.

Keywords: historical political science; political institutions of medieval Russia; old Russian society; Kievan Rus

INFORMATION ABOUT THE AUTHORS

\begin{tabular}{r|l} 
Ermakov, Dmitry N. & $\begin{array}{l}\text { E-mail: dermakow@mail.ru } \\
\text { Doc. Sc. (Economics), Professor }\end{array}$ \\
Popov, Grigory G. & $\begin{array}{l}\text { E-mail: popov-gg@ranepa.ru } \\
\text { Cand. Sc. (Economics), Senior researcher }\end{array}$ \\
Kaninskaya, Galina N. & $\begin{array}{l}\text { E-mail: kanin@uniyar.ac.ru } \\
\text { Doctor Sc. (History), Professor }\end{array}$ \\
Marasanova, Victoria M. & $\begin{array}{l}\text { E-mail: vmm@uniyar.ac.ru } \\
\text { Doctor Sc. (History), Professor }\end{array}$
\end{tabular}

For citation: Ermakov D. N., Popov G. G., Kaninskaya G. N., Marasanova V. M. Institutional and political development of the Russian state in the context of the theory of A. Greif // Social'nye i gumanitarnye znanija. 2020. Vol. 6, No 4. P. 324-333. (in Russ.)

(C) Ermakov D. N., Popov G. G., Kaninskaya G. N., Marasanova V. M., 2020

This is an open access article under the CC BY license (https://creativecommons.org/licenses/by/4.0/) 


\title{
Институционально-политическое развитие русского государства в контексте теории А. Грайфа
}

\author{
Д. Н. Ермаков ${ }^{1}$, Г. Г. Попов ${ }^{2}$, Г. Н. Канинская ${ }^{1}$, В. М. Марасанова ${ }^{1}$
}

${ }_{1}^{1 Я р Г У, ~ у л . ~ С о в е т с к а я, ~ 14, ~ Я р о с л а в л ь, ~ 150003, ~ Р о с с и и ̆ с к а я ~ Ф е д е р а ц и я ~}$

2РАНХиГС, пр. Вернадского, 82, корпус 2, Москва, 119571, Российская Федерация

DOI: $10.18255 / 2412-6519-2020-4-324-333$

Научная статья

УдК 321.1; 328.188; 94 (47) “1130-1650”

Полный текст на русском языке

Целью настоящей статьи является тестирование концепции А. Грайфа на предмет действия принципа установления баланса интересов в русском обществе в условиях нарастания внешних угроз. Выявляется значение веча как института, отражавшего стремление к установлению баланса интересов элит в русском обществе. Прослеживаются изменения значения традиций самоуправления в русских землях с нарастанием военных угроз. Определяется содержание баланса интересов в средневековом русском обществе. Проблемный метод исторического анализа применяется к изучению политических процессов средневековой России, на первый план выдвигается проблема народоправства. Концептуальная идея А. Грайфа подтверждается в русской средневековой истории. Отклонения от выведенного А. Грайфом правила при определенных внешних условиях ведут общество к кризисам. Авторы указывают, что ослабление военного давления на Северо-Восточную Русь со стороны номадов (1408 г.) позволило московским князьям сконцентрировать усилия на борьбе с потенциальной внутренней оппозицией и с другими ветвями Рюриковичей, занимавших великие столы, а также против Новгородской республики, в которой воплотился древний славянский государственный порядок. В ходе этой борьбы был нарушен баланс интересов между стратами русского общества, что в итоге вылилось в установление жестокого крепостного права и реакционной формы централизованного управления государством - самодержавия. В Юго-Западной и Северо-Западной Руси такие условия не сложились, поэтому старый славянский порядок там долго сохранялся, но в силу военно-политических причин государствам в этих регионах не удалось сохранить независимость.

Ключевые слова: историческая политология; политические институты средневековой России; древнерусское общество; Киевская Русь

ИНФОРМАЦИЯ ОБ АВТОРАХ

Ермаков, Дмитрий Николаевич

Попов, Григорий Германович

Канинская, Галина Николаевна

Марасанова, Виктория Михайловна
E-mail: dermakow@mail.ru

Доктор экономических наук, профессор

E-mail: popov-gg@ranepa.ru

Кандидат экономических наук, старший научный сотрудник

E-mail: kanin@uniyar.ac.ru

Доктор исторических наук, профессор

E-mail: vmm@uniyar.ac.ru

Доктор исторических наук, профессор

Для цитирования: Ермаков Д. Н., Попов Г. Г., Канинская Г. Н., Марасанова В. М. Институциональнополитическое развитие русского государства в контексте теории А. Грайфа // Социальные и гуманитарные знания. 2020. Том 6, № 4. С. 324-333.

(C) Ермаков Д. Н., Попов Г. Г., Канинская Г. Н., Марасанова В. И., 2020

Статья открытого доступа под лицензией СС BY (https://creativecommons.org/licenses/by/4.0/) 
Проблема становления русской государственности продолжает привлекать внимание исследователей самого широкого профиля, в том числе и политологов, и не только отечественных, но и зарубежных. В имперский и советский периоды в центр причин возникновения русского централизованного государства в XIV-XV вв. специалисты помещали борьбу с татаро-монгольскими завоевателями. Подобный взгляд на генезис Московской Руси сохранился в мэйнстриме российской науки и в постсоветский период. Соответственно, основной причиной поражения русских княжеств в борьбе с ордынцами называлась и до сих отмечается политическая раздробленность, вызванная многочисленными конфликтами в «политической семье» Рюриковичей за обладание княжескими престолами.

Вместе с тем заслуживает внимания концепция А. Грайфа, который рассматривал сходную политическую ситуацию на примере Генуэзской республики XII в. [1]. По мнению А. Грайфа, внешние угрозы приводят не только к централизации власти в государстве, но и к установлению баланса интересов в обществе, что выражается в первую очередь в конституционном порядке (конституционном в широком смысле этого слова). Следуя логике рассуждений А.Грайфа, можно сделать вывод о том, что благодаря чётко установленному балансу сил Генуя сохранила и укрепила республиканский строй в XII в., несмотря на внешнее военное давление. Другой зарубежный политолог К. Литткенс показал, что аналогичный Генуэзской республике принцип действовал в древнегреческих полисах на стадии их ранней истории [2, p. 19]. К. Литткенс доказывает, что усилия по установлению единоличной власти в условиях серьезных внешних угроз оказывались контрпродуктивными, поэтому политические элиты стремились в древнегреческих полисах поддерживать баланс интересов, следствием чего стало введение в политическую жизнь законодательных кодексов в этих государствах [2, Р. 19-20].

Разумеется, примеры Генуи по позднему Средневековью и Древней Греции, на первый взгляд, далеки от Московской Руси, но только на первый взгляд: политологами давно выявлена и доказана универсальность ряда социальных и политических законов. В этом контексте бросается в глаза тот факт, что Русь IX-XVI вв. представляла собой феномен, при котором централизация и децентрализация в ее государственных образованиях развивались безотносительно нарастания или спада внешних угроз, за исключением эпохи правления Ивана Грозного. Однако знаменитое отражение нашествия Сахиб Гирея в 1541 г. произошло в условиях слабой монархической власти на фоне усиления влияния боярских кланов в Москве. Тогда русское государство продемонстрировало высокий технический и организационный уровень своей обороны перед лицом реформированного по образцу Османской империи Крымского ханства (крымские татары могли вывести к границам Московского княжества войско численностью более 30000 человек). Данный феномен можно объяснить, обратившись к теории А. Грайфа. В таком случае становится понятно и объяснимо, что в интересах региональных элит было сохранение автономии и даже ее развитие вплоть до обретения полной независимости или вхождения в состав другого государства (например, Великого княжества Литовского - ВКЛ).

Как показал отечественный специалист М. А. Несин, успешность русского средневекового войска зависела не столько от централизации государственного управления, сколько от логистики и, соответственно, экономических ресурсов для обеспечения военных [3; 4]. Средневековые русские люди это понимали, поэтому потребность в высокой централизации на уровне крупных территориальных комплексов (напри- 
мер, уровня Московского царства XVII в.) у них отсутствовала, особенно ярко это проявилось в отношении населения к княжеской власти в Северо-Западной и Западной Руси в монгольский период.

Более двух столетий в российской историографии, как было сказано выше, генезис централизованного государства и, соответственно, самодержавия рассматривался через призму реакции русского общества на внешние угрозы. Из этого вытекал вывод, что русские отказались от гражданского общества и парламентаризма в пользу безопасности на фоне сильного военного давления как с Востока (государства номадов), так и Запада (в основном Речь Посполитая и ранее ВКЛ). Однако, несмотря на то, что уровень внешних угроз значительно вырос в первой половине XIII в., в русских землях продолжался процесс политической дезинтеграции, впоследствии еще увеличилось количество как удельных, так и великих княжеств. Правда, власть великого князя превратилась в номинальный институт, усиление Московского дома объяснялось и объясняется хорошими отношениями его представителей с Золотой Ордой (передачей ханами Москве права сбора выхода), но не получением ими статуса великих князей владимирских.

Для средневековой Руси показателем стремления общества к поддержанию баланса интересов выступает институт веча, по которому проследить политику элит по поддержанию конституционного порядка в противовес попыткам установления единоличного правления (самодержавия) представляется весьма легким. Самодержавное правление нередко рассматривалось в русских землях как произвол, то есть как политические действия, противоречащие установившемуся в обществе порядку, или согласию. В этой связи правомерно сопоставить проявление вечевых традиций в русских землях конца киевского и монгольского периодов с нарастанием / снижением внешних угроз, тестируя тем самым концепцию А. Грайфа на примере истории средневековой Руси. В этом суть метода проблемного исторического анализа и подхода к изучению политических процессов средневековой России.

В средневековой Руси существовало несколько ограничений власти русского князя, которые, судя по всему, вытекали из неписаной древнерусской конституции [5, с. 86]. Во-первых, князь не имел права убить или сильно покалечить другого князя. Во-вторых, один князь не имел права лишить абсолютно волостей другого князя, на это не имел прав даже съезд князей. Эти ограничения стали весомыми причинами политической раздробленности Руси [6, с. 86].

Вторая группа ограничений уже находилась в сфере отношений князя с дружинниками и боярами. Любой Рюрикович был обязан в ходе принятия стратегического решения советоваться со старшими дружинниками или боярами. Отсюда следовало другое ограничение - неуважение князем дружинников влекло за собой отъезд последних к другому князю [6, С. 89]. Впрочем, такой отъезд мог произойти и по другим причинам [6].

Третьим ограничением власти князя было вече, не всегда оно явно выступает в летописях как таковое, но подразумевается, что жители города именно организованно выносили свое решение. К тому же, в историографии до сих пор нет однозначного мнения насчет того, было ли вече действительно органом народоправства или же являлось выразителем интересов региональных олигархий [6, С. 90]. Мы считаем, что верно то и другое, региональная элита вынуждена была считаться с мнением большинства, но речь идет, естественно, о свободных горожанах и зажиточных крестьянах, под ними в средневековой Руси понимался народ, что характерно для всех индоевропейцев с древнейших времен. Однако нерегулярность вечевых собраний 
даже в Новгороде и Пскове [7, с. 91] указывает на архаичность данного института и на существование более прочных властных структур боярской власти.

Разумеется, мнение веча выражало желания элитарных сегментов общества, в первую очередь бояр. Ближе к середине XII в. можно увидеть по летописям усиление значения веча, что означает политическое укрепление региональных элит, которые стремятся заставить княжескую власть прислушиваться к своему мнению. В 1136 г. окончательно оформляется через решение веча приоритет боярской власти в Новгороде, в 1138 г. черниговская знать потребовала на вечевом собрании от Всеволода Ольговича остаться в волости, чтобы принять бой со своим соперником киевском князем Ярополком Владимировичем, в середине XII в. киевляне неоднократно через вече выражали свои политические симпатии или антипатии к тем или иным князьям в ходе активизации борьбы между последними за киевский стол [6, с. 96]. В 1155 г. Изяслав Давыдович ответил Юрию Долгорукому на требование последнего оставить Киев, что править его в городе поставили киевляне [6, С. 97].

Очевидно, богатые горожане и бояре стремились установить свой порядок в русских землях, намереваясь положить конец княжеским междоусобицам, которые, как известно, велись из-за отсутствия упорядоченного законодательно престолонаследия. Однако видна и другая проблема, вызвавшая политическую активность региональных элит: слишком сильная власть князя наносила ущерб их экономическим интересам, поэтому те же киевляне или новгородцы желали видеть у себя слабого в правах князя. Но все это происходило на фоне возрастания военной угрозы для русских земель, но не со стороны внешних врагов, а со стороны своих же князей, которые часто привлекали в свои войска иностранные контингенты, например, традиционных для русских врагов - половцев. Русь к середине XII в. превратилась в конфедерацию, это делало тех же самых владимирцев в глазах киевлян чужаками. Например, жители Рязанщины называли Русью только южнорусские княжества [6, С. 102], очевидно, слабо ассоциируя себя с последними.

Что касается четвертого типа ограничений - церкви, то мы не видим в киевский период большого значения этого фактора в русской политике, роль Православной церкви возросла в Северо-Восточной Руси уже в монгольский период. Исключение здесь составил Великий Новгород, где сложилась уникальная в русской истории ситуация, когда значительная часть исполнительной власти и верховная судебная власть были переданы еще в киевский период епископу (с 1165 г. новгородские епископы получили сан архиепископов), который избирался не только богатыми горожанами, но и свободными новгородцами среднего и малого достатка [5, с. 129]. Епископ также являлся председателем Совета господ [5] (орган, смешивавший в себе функции исполнительной и законодательной властей, но больше имевший функции постоянного малого законодательного собрания).

Совет господ существовал и в Пскове, и, судя по всему, данный институт был распространен в киевский период в других городах, но за пределами Северо-Западной Руси он не имел столь большого значения как ограничитель княжеской власти. Перед падением Новгородской республики в конце XV в. Совет господ состоял приблизительно из 50 человек [5, С. 132].

То, что политическая раздробленность вытекала, помимо конфликта внутри династии Рюриковичей, из воли региональных элит, подтверждается материалами по истории Галича и Волыни. Практически с последней четверти XII в. галичане уже сами определяли себе князя, как это начали ранее делать новгородцы. Правда, едва ли этот принцип был заимствован галичанами с Севера. Произошло возрождение 
древних славянских принципов управления государством, что было вызвано как ослаблением княжеской власти, так и нарастанием для некоторых русских регионов внешнеполитических угроз, в случае с Галичем это были претензии Венгрии на земли Юго-Западной Руси. В случае с Галичем очень четко видна роль бояр как региональной силы, ограничивавшей власть князя, одним из инструментов этого было вече.

Почему вече и боярство теряют власть незадолго после нашествия монголов на Русь? Южнорусские города пришли в упадок. В Северо-Восточной Руси города тоже сильно пострадали, особенно Владимир, который пришлось восстанавливать практически с нуля. Верхнее Поволжье при этом не имело многочисленного городского населения вплоть до конца монгольского периода. Поэтому вечевые традиции за пределами Северо-Западной Руси имели в монгольский период небольшую социальную базу. Кроме того, мы имеем мало летописных сведений о первой трети монгольского периода, чтобы делать однозначные выводы о развитии русских институтов после Батыева погрома.

По К. Литткенсу, кодификация права следует за установлением баланса интересов между политическими группировками, к такому выводу он пришел на базе анализа раннего развития древнегреческих полисов. Из-за дефицита письменных материалов по внутриполитической истории русских земель монгольского периода нам сложно, за редким исключением, определить, какие и как долго клановые группировки действовали в тех же Новгороде и Пскове. Однако датировка принятия законодательных кодексов позволяет нам лучше понять политические и социальные условия, складывавшиеся в процессе эволюции русской государственности в монгольский период.

Псковская судная грамота (ПСГ) в неполном виде была принята вечем республики в 1397 г. [8, с. 321-343]. Аналогичный новгородский законодательный кодекс был принят в 1440 г. (самая ранняя предположительная датировка). В 1488 г. появляется Белозерская уставная грамота, повлиявшая на московское законодательство. Белозерское удельное княжество окончательно юридически утратило независимость в 1486 г., но при этом уставная грамота все-таки признается Иоанном III. Белоозеро (точнее, его князья и бояре) имело особый статус в военной организации Московской Руси еще со времен Дмитрия Донского, чем объяснима высокая роль его уставной грамоты в формировании единого русского законодательства в конце XV в. В то же время Белозерская уставная грамота является признаком поиска баланса интересов между элитарными группировками русских регионов и центральной властью, а также между купцами и земельной аристократией.

Заметим, что между принятием ПСГ (она тоже сильно повлияла на законотворчество в Московском царстве в конце XV в.) и Белозерской уставной грамоты лаг примерно в 90 лет. Соответственно, Северо-Западная Русь столкнулась с достаточно серьезной военной угрозой в середине, если не в начале XIV в., когда Северо-Восточная Русь переживала период «затишья» на фоне ослабления Золотой Орды из-за внутренних конфликтов в этом государстве (насильственная религиозная реформа хана Узбека и последовавшая за ней «великая замятня в Орде»). Разгром Твери в 1328 г. здесь стал исключением, к тому же, Тверское княжество занимало обособленное положение в Северо-Восточной Руси. Конфликт между Московским и Тверским домами Рюриковичей следует рассматривать как борьбу между региональными кланами за господство в Низовских землях, что означает отвлечение элит от борьбы с внешними врагами (в данном случае ордынцами) на соперничество за верховную власть внутри своего государственного образования (конфедерация Владимиро-Суздальской Руси). 
ПСГ оказала влияние на разработку Иоанном III и его чиновниками Судебника 1497 г.[8, с. 24-27], несмотря на то, что ПСГ была построена частично на немецком праве либо ее нормы были очень похожи на немецкие [9, с. 24-27]. Это указывает на то, что Москва в конце XV в. искала компромисс с протобуржуазным псковским обществом перед лицом общей опасности в лице ВКЛ, которое еще и пошло на союз с Ливонским орденом, что означало формирование вдоль почти всего западного фронтира Руси мощной военной коалиции.

В 1299 г. ливонские рыцари начинают очередное, но особо сильное наступление на псковские земли. До этого русские войска воевали преимущественно на территории Ливонского ордена, правда, им приходилось часто вести и оборонительные бои, но все-таки крупные военные события происходили преимущественно на территории противника (даже легендарное Ледовое побоище 1242 г. состоялось в пограничной полосе). Однако весной 1299 г. рыцари потерпели тяжелое поражение, после чего наступило относительное затишье, которое было нарушено в мае 1323 г. попыткой немецких рыцарей взять Псков посредством использования технического превосходства (тогда русские испытали на себе всю мощь западной феодальной революции в военном деле). Город чуть не пал, псковичей спасли союзные им литовцы (вероятнее всего, речь идет о предках белорусов либо латышей, либо о тех и других, проживавших на северо-западе ВКЛ).

В 1341 г. поход немецких рыцарей повторился. На этот раз ливонцы и союзные им контингенты действовали осторожно, построив недалеко от Пскова крепость (это была старая немецкая стратегия, выработанная в ходе движения тевтонских завоевателей на Восток еще во времена Каролингов). Новгород отказал в помощи Пскову (скорее всего, из коммерческих соображений, на новгородскую знать тогда сильно влияла Ганза). Тогда псковская военная знать прибегла к привлечению на свою сторону сельских жителей своего пограничья с Ливонским орденом (вероятнее всего, это были местные финские племена, которых связывали с Псковом только даннические отношения). ВКЛ предоставило помощь Пскову, но не столь значительную, поэтому немцам удалось осадить Изборск, но эту крепость они взять не смогли, правда, Изборск был уже на грани капитуляции из-за дефицита воды. После тех событий псковичи пригласили на княжение сына Ольгерда Андрея, правда, изначально они хотели видеть своим князем Ольгерда, но последний отказался.

Таким образом, между 1299 и 1341 гг. военное давление на Псковскую республику заметно нарастает, это государство вынуждено перейти от наступления к обороне, при этом силы между псковичами и ливонцами оказались явно неравны уже к 1323 г. Возникла в этой связи необходимость консолидации между городским и сельским населением, как, очевидно, и консолидации внутри городского населения республики. Вслед за чем возникает кодификация законодательства Псковской республики.

В ситуации с призванием сына Ольгерда Андрея на княжеский стол в Пскове мы видим возможность для Гедиминовичей усилить свою позицию в этом государстве, однако этого не происходит, сам Ольгерд скептически отнесся к перспективам ВКЛ на Псковщине. Причиной тому была необходимость концентрации усилий монархии в самом ВКЛ на борьбе с немецкими крестоносцами, то же самое касается затем и князя Андрея в Пскове, ресурсов для узурпации власти в этом государстве у Гедиминовичей не было. Появление к началу XV в. у псковичей закованных в броню всадников (летописная «железная рать») снизило потребность их республики в по- 
мощи со стороны ВКЛ, однако, очевидно, импорт достижений «феодальной революции» в военном деле вел к образованию в псковских землях достаточно политически сплоченного военного сословия (некий отдаленный аналог европейского рыцарства).

В 1400 г. архиепископ Новгородский Иоанн приказал возобновить строительство укреплений стен Детинца «от Бориса и Глеба», это было знаковое событие, связанное с ростом военной угрозы со стороны Москвы в связи со спором между ней и Новгородской республикой по поводу Подвинья и других территорий.

Основные доходы Новгород получал от поступлений пушнины с целью их продажи Ганзе от финно-угорских народностей. Бассейн Северной Двины в этом смысле был экономически важным регионом для новгородцев. Московское государство тогда было еще слабым и раздираемым внутренними распрями, но в 1435 г. новгородцы все-таки признали окончательно за Василием II Бежецк, Волок Ламский и Вологду (они были взяты Василием I в 1393 г., но новгородцы продолжали считать эти волости своими, из-за чего затем несколько раз воевали с московитами [10, c. 164]). Через пять лет появился новгородский законодательный кодекс, что, по К. Литткенсу, следует рассматривать как следствие консолидации сил новгородского общества перед внешней угрозой.

B XIV в. в Московском государстве появляется много жалованных грамот, которые составлены на основе византийского законодательства. Это означает, что Московская ветвь Рюриковичей порвала с Русской правдой и древними славянскими традициями, что, несомненно, является сознательным шагом к провокации дисбаланса интересов в Северо-Восточной Руси на фоне ослабления внешнего военного давления. В этой связи стоит сказать, что в том же веке московские князья отдают приоритет в землевладении и привилегиях в государстве церкви, что также является признаком концентрации их усилий на внутренней борьбе за власть.

В 1397 г. появляется Двинская уставная грамота, определяющая нормы самоуправления в соответствующем регионе. Однако Подвинье является особым регионом в системе русских земель монгольского периода, и этот регион больше тяготел к Северо-Западной Руси. Между Двинской уставной грамотой и Судебником Иоанна III ровно сто лет. Соответственно, потребность в установлении баланса интересов в Московском государстве возникает где-то в разгар правления Иоанна III, когда обострилась борьба русского государства с Большой Ордой и ВКЛ, а также Казанским ханством.

При Иоанне IV появляются губные и земские грамоты, однако это уже отголоски политики Иоанна III в законодательной и управленческой сферах, опричнина и репрессии Ивана Грозного перечеркнули все усилия его деда. Россия превратилась в классическую восточную деспотию к концу XVI в., потерпев при этом в конце правления Ивана Грозного крупное военное поражение от польского короля Стефана Батория, что потребовало уже после смерти Иоанна IV поиска путей для новой консолидации общества, этот поиск оказался неудачным, что привело к Смуте, в ходе которой была предпринята попытка выработки конституционного порядка. Примечательно, что после битвы при Молодях, когда русские войска понесли большие потери и чуть не допустили полного разгрома Московского государства крымскими татарами, происходит отмена опричнины (1572 г.). То есть в 1572 г. начался переход от дисбаланса интересов в обществе к поиску баланса.

Подводя итоги, подчеркнём, что если посмотреть на всю русскую историю до реформ Петра Великого через призму концептуальных идей А. Грайфа и К. Литт- 
кенса, то можно сделать вывод о том, что внутренняя интеграция общества через попытки правивших элит достичь баланса интересов совпадает с периодами нарастания внешнеполитической напряженности. Между тем репрессивная политика, направленная на подавление политических конкурентов внутри государства, усиливается в момент снижения внешней опасности. В этой связи отчётливо усматривается последовательность смены фаз, или циклов, двойственного состояния государственной системы: от периода, когда достигается компромисс между элитами, к репрессивному государству с гипертрофированным доминированием одной правящей группировки.

Бросив ретроспективный взгляд на поздний киевский период, мы увидим, что баланс интересов достигается в Новгородской республике между 1136 и 1165 гг. В 1136 г. бояре окончательно берут власть в этой республике, в 1165 г. новгородский епископ становится архиепископом, что, надо понимать, увеличивает политический вес этой фигуры в данном государственном образовании, архиепископ становится консолидирующим новгородское общество центром, но он не имеет диктаторской власти. Достижение баланса интересов в новгородском обществе происходит на фоне роста количества и силы междоусобных войн на Руси, для Новгорода эти конфликты были фактически внешней угрозой. Очевидно, такие же шаги по ограничению княжеской власти и консолидации региональных элит в отстаивании своих интересов имеют место во второй половине XII в. и в других русских землях, что, повторимся, было ответом на княжеские междоусобицы, сопровождавшиеся нередко «наведением половцев» на Русь.

Между 1393 и 1440 гг. мы видим тот же процесс консолидации новгородцев, что стало ответом на военную экспансию Москвы на север и северо-запад.

В Московской Руси баланс интересов устанавливается ближе к 1497 г. (дата издания Судебника Иоанна III), что объяснимо нарастанием угрозы со стороны ВКЛ и ужесточением конфликтов с Казанским ханством. В монгольский период Московский дом Рюриковичей в основном наступал против своих конкурентов в рамках в первую очередь Владимиро-Суздальского княжества (фактически конфедерации удельных княжеств), редко достигая с ними политического компромисса. Процесс консолидации русского общества продолжается практически до падения Казани, после чего группировка элитарных сегментов общества вокруг фигуры Ивана Грозного наносит удары по своим потенциальным политическим конкурентам, что создает напряженность в обществе, снижает его обороноспособность и ведет к кризису начала 1570-х гг., когда крымские татары чуть не взяли Москву.

Избрание на царство в 1613 году Михаила Романова можно считать вехой, обозначающей новую консолидацию элит в русском обществе и выработку ими баланса интересов вокруг в целом нейтральной политически фигуры. За этим следует новая кодификация русского законодательства в 1648 г. Все это происходит на фоне высокого военного напряжения на западном фронтире Московской Руси, откуда постоянно исходила угроза от Речи Посполитой. Вероятность нового польско-литовского вторжения значительно ослабевает к 1680 г., в то же время менее агрессивной по отношению к России становится Османская империя, против ее вассала - Крымского ханства - Москва стала уже в состоянии самостоятельно выступать. В этих условиях развивается деконсолидация российских элит и общества в целом, что вылилось в итоге в репрессивные реформы Петра Великого.

Таким образом, русская история демонстрирует нам, что внешняя угроза влечет за собой установление баланса интересов в обществе или, во всяком случае, 
стремление элит к таковому. Применим ли данный принцип к анализу истории обществ индустриальной цивилизации? Мы положительно отвечаем на этот вопрос. Правда, мы признаем, что возможны отклонения от данного принципа (аномальные случаи), в результате чего общества переживали тяжелые кризисы.

Президент Российской Федерации Владимир Владимирович Путин, выступая перед участниками дискуссионного клуба «Валдай», подчеркнул: «Для россиян, для России вопросы «кто мы?», «кем мы хотим быть?» звучат в нашем обществе всё громче и громче. Мы ушли от советской идеологии, вернуть её невозможно. Приверженцы фундаментального консерватизма, идеализирующие Россию до 1917 года, похоже, так же далеки от реальности, как и сторонники западного ультралиберализма. Очевидно, что наше движение вперёд невозможно без духовного, культурного, национального самоопределения, иначе мы не сможем противостоять внешним и внутренним вызовам» [11]. Эти слова как нельзя более ясно выражают необходимость использовать весь методологический потенциал современной науки, чтобы создавать объективную оценку российского политического процесса в его современном и историческом преломлении.

\section{Ссылки / References}

1. Greif A. On the Political Foundations of the Late Medieval Commercial Revolution: Genoa During the Twelfth and Thirteenth Centuries // Journal of Economic History. 1994. № 54. P. 271-287.

2. Lyttkens C. H. Reflections on the Origins of the Polis: An economic Perspective on Institutional Change in Ancient Greece // Constitutional Political Economy. 2006. № 17 (1). P. 31-48.

3. Несин М. А. Из истории логистики русских войск в XV-начале XVI в. (отзыв на работу Пенского В. В. «...И запас пасли на всю зиму до весны»: логистика в войнах Русского государства эпохи позднего Средневековья - раннего Нового времени») // История военного дела: исследования и источники. 2016. T. VIII. С. 134-166.

4. Несин М. А. К вопросу о логистике Куликова поля // Вестник Удмуртского университета. Серия: философия и филология. 2018. Т. 28. Вып. 1. С. 70-80.

5. Питюлько Г. Н. Из истории вечевого строя Новгорода и Пскова // Управленческое консультирование. 2013. № 11. С. 128-134.

6. Короленков А. В. «Всех нас старее и отецъ твои, но с нами не умеете жити»: князь, норма и реакция на ее нарушение в домонгольской Руси // История и историческая память. 2013. № 7-8. С. 80-103.

7. Пашковский П. И. Истоки российского парламентаризма и внешняя политика государства: опыт вече, Боярской думы и Земского собора // International Journal Of Professional Science. 2016. C. 89-96.

8. Российское законодательство X-XX веков в 9 т. Т. 1. Законодательство Древней Руси. М.: Юридическая литература, 1984. 432 с.

9. Переверзев А. С. Византийское право как источник Псковской судной грамоты // Юридические науки. 2015. № 3. С. 24-27.

10. Колесников П. А. Вологда в политических планах Московского княжества (к постановке вопроса) // Россия на путях централизации. Сборник статей. М.: Наука, 1982. С. 160-166.

11. В. Путин: Вопрос обретения и укрепления национальной идентичности носит для России фундаментальный характер // Путин сегодня. 05.01.2014. URL: //https://www.putin-today.ru/archives/50 (дата обращения: 01.11.2020). 